Bull. Geol. Soc. Finland 41: 135-150 (1969)

\title{
LAND/SEA LEVEL CHANGES IN SOUTHERN FINLAND DURING THE FORMATION OF THE SALPAUSSELKÄ ENDMORAINES
}

\author{
J. J. DONNER
}

Department of Geology and Palaeontology, University of Helsinki

\begin{abstract}
The altitudes of delta plains of the Salpausselkä endmoraines and of eskers, as well as some determinations of the highest beach level, were used in the study of land/sea level changes. An area south of Hämeenlinna in southern Finland was studied in more detail and compared with Salpausselkä I at Lahti and Utti. It was found that there is a zone in the Salpausselkä belt, partly including Salpausselkä I, and reaching to a line inside Salpausselkä II, in which the outwash features were formed during a high position of the water level, when the Baltic Ice Lake was dammed and its level higher than the sea level. The transgression began $8600-8700$ B.C. and ended with the drainage of the Baltic Ice Lake at Billingen in Central Sweden in 8213 B.C., when the water level dropped to the Yoldia level, Y I. Before the transgression the deltas, which mostly belong to Salpausselkä I, were formed at a low position of sea level, the $\mathrm{g}$ level. A curve of the land/sea level changes covering the last 11000 years was constructed on the basis of the results from the present study and earlier investigations in the same area.
\end{abstract}

\section{Introduction}

Using the levelled profiles across the endmoraine features of Salpausselkä I and Salpausselkä II published by Leiviskä (1920), Ramsay (1922) concluded that the endmoraines often consist of marginal terraces with an even, towards the distal part slightly sloping delta plain. Preserved meltwater channels on the surface in some deltas show that they were partly supra-aqueous and Ramsay demonstrated that the distal edge of the delta plain, which often has a well-developed shore bar, corresponds to the water level at the time of the formation of the delta (see also Sauramo 1928). Further, Ramsay showed that by using the altitudes of the distal edges of the various marginal deltas, synchronous isobases could be drawn for the periods during which Salpausselkä I and Salpausselkä II were formed respectively. Later Sauramo $(1934,1937)$ used the marginal deltas of the Salpausselkäs, also the features of Salpausselkä III, for a detailed analysis of the fluctuations of water level of the Baltic Ice Lake, fluctuations interrupted by drops in the water level down to sea level at periods when a connection with the ocean was established. Thus Sauramo separated in the Salpausselkä belt the following levels (terminology according to Sauramo 1958, see also Donner 1965), which are also shown in Fig. 4. 
Salpausselkä I

B I

》)

Area between Ss I and Ss II

g

B II

Salpausselkä II

B III

Area between Ss II and Ss III

Y I

B IV

B V

B VI

Salpausselkä III

Highest Yoldia level after final drainage of Baltic Ice Lake

Y I

According to this scheme, in which each B level corresponds to a particular level of the Baltic Ice Lake, Salpausselkä I has an older series of deltas formed up to the B I level and a series of younger deltas, particularly in southwestern Finland, at the g level 25 m below B I. The lower level was correlated with the corresponding level of the ocean in northern Fennoscandia and therefore named after the $\mathrm{g}$ level in the division of shorelines used by Tanner (1930, see Sauramo 1958, p. 75). The distribution of the B I and g deltas, as well as the B III level, is shown in Fig. 1. During the retreat of the ice margin from Salpausselkä I to Salpausselkä II the Baltic Ice Lake was once more dammed up, to the B II level and the Salpausselkä II marginal deltas were formed at the B III level. When the ice margin was just inside Salpausselkä II the Baltic Ice Lake was again drained, to the Y I level and a new damming up followed. The B IV and $\mathrm{B} \mathrm{V}$ levels represent the rise of water level up to the level, B VI, at which the marginal deltas of Salpausselkä III were formed. After this occurred, according to Sauramo, the final drainage of the Baltic Ice Lake, during which the water level dropped 27-28 $\mathrm{m}$ down to Y I, the highest Yoldia level, the same level at which the water had stood already immediately after the formation of Salpausselkä II. As many of the sites for varve measurements used by Sauramo (1918, 1923) were in the Salpausselkä belt, as well as north and south of it, he was able to connect the varve chronology with the various endmoraines and in this way also with the levels sepa- rated in the shoreline displacement (Sauramo 1934, 1937). In Sauramo's varve chronology the drainage of the Baltic Ice Lake after the formation of Salpausselkä II is the zero year \pm 0 . The halt of the retreating ice margin began at Salpausselkä I at about — 660 and the last drainage of the Baltic Ice Lake after Salpausselkä III was dated to +292 . All three Salpausselkäs were thus formed in about 950 years, the two first in 660 years.

The above-mentioned scheme of the fluctuations of the water level of the Baltic Ice Lake and their dating was used by Sauramo in his monograph on the history of the Baltic (Sauramo 1958), which included results from his earlier works on the subject. The nomenclature used here is from this monograph, as mentioned in connection with the list above. In an interpretation of earlier investigations of raised beaches, marginal deltas, varve chronology and pollen stratigraphy in south-western Finland it was found that there is no conclusive evidence of a damming up of the water level after the dtainage of the Baltic Ice Lake in the year \pm 0 immediately after the formation of Salpausselkä II (Donner 1964). Similarly, in a study especially dealing with the question of the damming up of the Baltic Ice Lake after Salpausselkä II had been formed and the existence of the levels B IV, B V and B VI, Okko (1965) concluded that the interpretation of the formation of the features used by Sauramo in demonstrating the damming up of the Baltic can not be considered correct and that the levels described as B IV, B V and B VI never existed. Thus, according to the above-mentioned new interpretations, the water level did not rise any more after the drainage following the formation of Salpausselkä II. That the final drainage of the Baltic Ice Lake took place when the ice margin stood immediately north of Salpausselkä II was already concluded by Ramsay (1917), in his study of the highest beach level, the highest limit at which the wate level stood during the retreat of the ice margin from southern Finland, as well as by Sauramo 


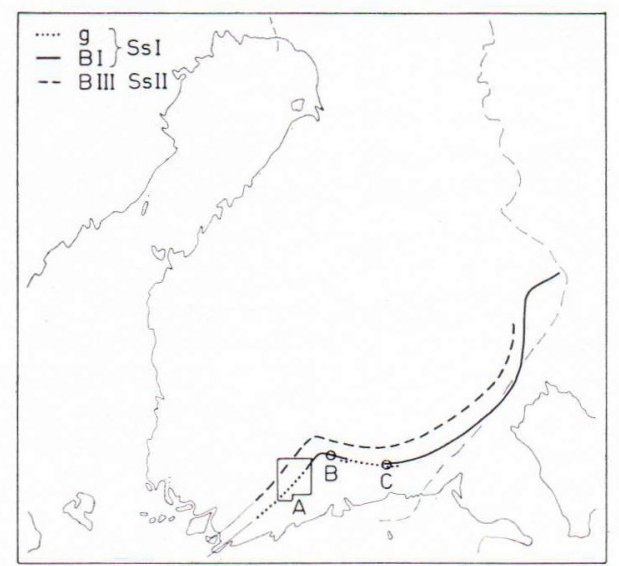

Fig. 1. The distribution in southern Finland of the delta plains at $\mathrm{g}$ level and B I level belonging to Salpausselkä I and the delta plains at B III level belonging to Salpausselkä II (modified after Sauramo 1958 and Hyvärinen 1966). A, area studied south of Hämeenlinna (see Fig. 2); B, Lahti; C, Utti.

in his earlier papers (see Sauramo 1933). The sudden lowering of the water level by $28-29 \mathrm{~m}$ was taken as proof of a drainage in a lake and not as a result of a sudden movement of the earth's crust.

Detailed investigations of features belonging to Salpausselkä II and north of it have made it possible to trace the position of the ice margin at the time of the drainage of the Baltic Ice Lake especially in the area south of Hämeenlinna, as seen from the results by Sauramo (1958, Fig. 19 p. 83) and Aartolahti (1968, Appendix I). The earlier fluctuations in water level in the Baltic Ice Lake, particularly the relationship between B I, g and B II (see Fig. 4) formed during and immediately after the formation of Salpausselkä I, have, however, received less attention after the time they were first described (Sauramo 1934, 1937). In the present study, therefore, the main emphasis is on the land/sea level changes at the time of the formation of Salpausselkä I even if Salpausselkä II was included. The area studied in more detail (Fig. 1) includes parts of the abovementioned area south of Hämeenlinna studied by Sauramo and also some of that studied by Aarto- lahti. In this area the B I and g levels both occur and their distribution and age relationship can therefore be studied. In addition to the area studied south of Hämeenlinna comparisons are made with other parts of the Salpausselkä belt, especially with the Lahti area, where B I is welldeveloped and $\mathrm{g}$ missing, and with Utti, where B I and g occur together.

The field work was mainly done in the summers of 1948 and 1968. Topographical maps in $1: 20000$ were used in the field and the observations later transferred to topographical maps in $1: 100000$. The maps of the superficial deposits in $1: 100000$, published by the Geological Survey of Finland and covering the whole area studied, were also used, particularly in tracing suitable sites and in locating earlier studied sites, which were also included in the study. An attempt was made to use sandur-deltas or marginal outwash deltas with an original delta plain (for terminology see Andersen 1960) of the Salpausselkä endmoraines, especially of Salpausselkä I, and also of similar features in the eskers, in determining the altitude at which the water level stood during various stages of the retreat of the ice margin. Determinations of the highest beach level, in cases where they are exeptionally clear and where their occurrence is of direct relevance to the problem dealt with, were also included in a few instances. On the basis of the varve measurements done by Sauramo in the area, the results could also be connected with the varve chronology (Sauramo 1918, 1923). As the area studied south of Hämeenlinna lies largely within the area which was earlier used in an analysis of the Lateglacial and Post-glacial emergence of south-western Finland (Donner 1964), the results from the present study can directly be compared with the earlier ones.

\section{The area south of Hämeenlinna}

The area studied is shown on the map in Fig. 2. The main endmoraines and eskers are outlined 


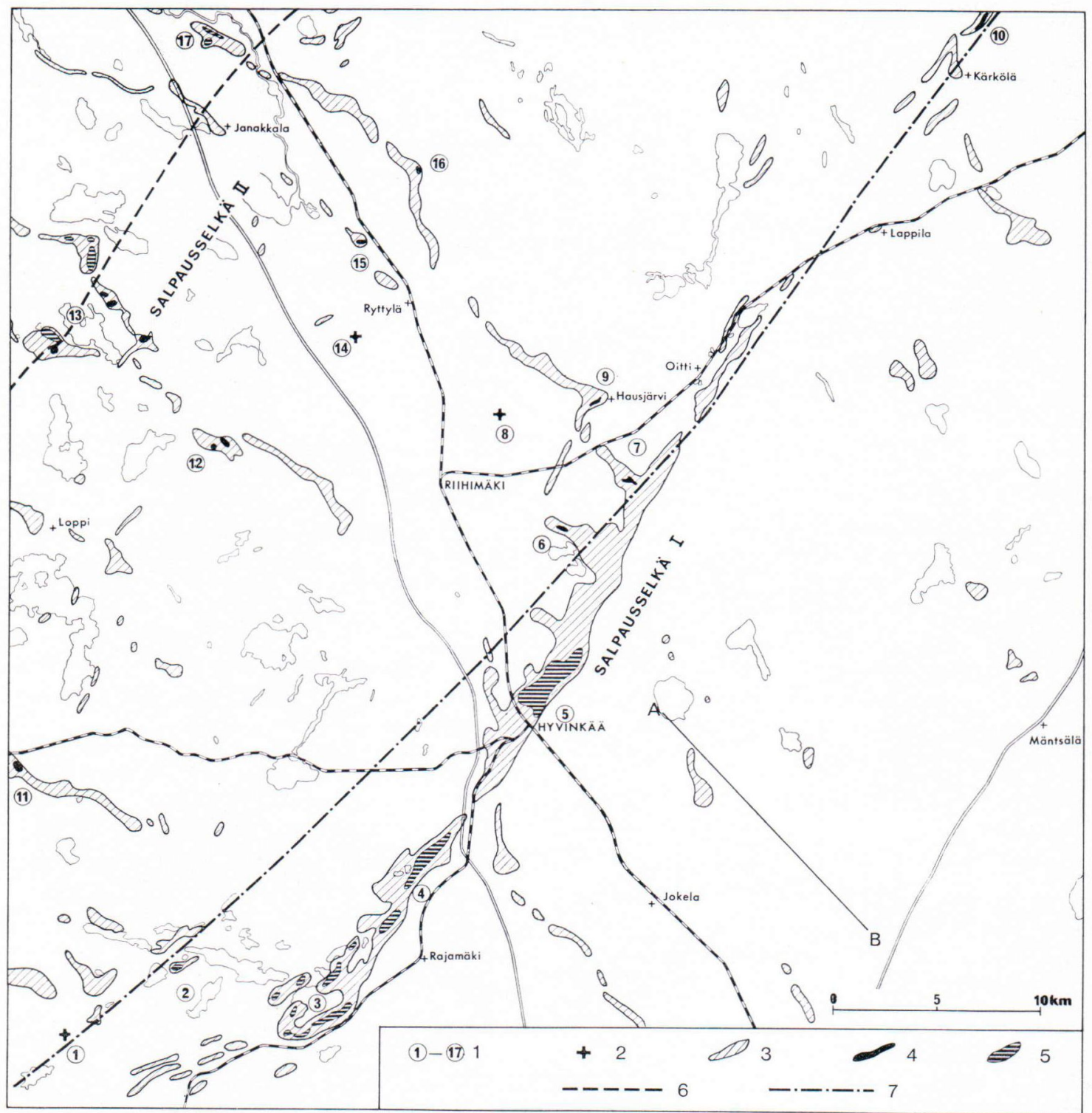

Fig. 2. Area studied south of Hämeenlinna (see Fig. 1). 1, site numbers used in the text; 2, highest beach level; 3 , esker or endmoraine; 4, delta plain representing one of the B levels; 5, delta plain representing either the $\mathrm{g}$ level or the Y I level; 6, line showing the approximate position of the ice margin at the time of the drainage of the Baltic Ice Lake from the B III level to the Y I level (based mainly on Aartolahti 1968); 7, line separating the delta plains formed at $\mathrm{g}$ level from delta plains or raised beaches formed at the B I level; A-B, base line for shoreline diagram in Fig. 3.

on the map according to the maps of the superficial deposits in $1: 100000$, in which these features on most maps are included under the heading of eskers and other glaciofluvial accu- mulations, separating them from gravel, sand and fine sand. In those instances, when deltas were closely related to the above-mentioned features but not marked on the maps as belonging 
to them, the outlines were changed to include them. The sandur-deltas and marginal deltas could, on the basis of their altitude, clearly be divided into two groups: those formed at either the $g$ level or Y I level, according to the division by Sauramo, and those formed higher at one of the B levels. These two groups were separated on the map in Fig. 2. The sites in which the highest beach level has been determined were marked separately. In the following description of the observations made at different sites in the area studied, including those by others, they are mentioned in the same order as they ate numbered on the map in Fig. 2. Several observations from a limited area were often treated as belonging to one single site. For each site the name of the parish or parishes to which it belongs is given after the name, as well as in brackets references to those papers in which the site has earlier been described or in which the significance of the site for the reconstruction of land/ sea level changes has earlier been discussed. Of the papers by Sauramo his monograph on the history of the Baltic (Sauramo 1958) was mainly used, as it includes the main results from his earlier papers.

1. Sudenkallio, Vihti (Sauramo 1958, p. 112). A thin layer of till covers the top of the hill Sudenkallio, but below an altitude of $150-152 \mathrm{~m}$ the bedrock is washed clean, especially on the southern and south-western side. This zone marks the highest beach level. On the nearby hill Männistönmäki, reaching an altitude of $157.5 \mathrm{~m}$, the highest signs of wave action are not equally clear.

2. Vihtijärvi, Vihti (Sauramo 1958, p. 85). A marginal delta, between the lakes Vihtijärvi and Alimmainen, with a plain at $124-125 \mathrm{~m}$.

3. Sääksjärvi, Nurmijärvi and Hyvinkää (Ramsay 1931, site no 182; Sauramo 1958, p. 84 ; Virkkala 1963, p. 14 15; Aartolahti 1968, p. 62). Around Sääksjärvi Salpausselkä I consists of several parallel moraines, some of which are deltas. The moraine on the south-eastern side of Sääksjärvi is in places a slightly undulating, towards the distal edge sloping delta plain at about $120 \mathrm{~m}$. The delta west of Sääksjärvi has on the surface a number of irregular ridges with coarse material, which indicate that the surface reaching somewhat above $120 \mathrm{~m}$ is here a sandur-delta, where only the distal part corresponds to the water level at the time of formation. The delta northeast of Sääksjärvi, forming a continuation of the abovementioned moraine on the other side of the lake, is similar in character, but here the ridges on the surface, especially in the proximal part, are clearer and are directed towards the more even distal delta plain at about $120 \mathrm{~m}$. The two deltas at approximately the same altitude north-west of Sääksjärvi, south-east of Vihtijärvi, have irregular surfaces rich in boulders.

4. Rajamäki, Nurmijärvi (Sauramo 1958, p. 84). North-west of Rajamäki is a marginal delta at about $120 \mathrm{~m}$, belonging to Salpausselkä I, and further northeast along the same moraine, near Herustenlammet, a more extensive delta, in which the plain rises from about $120 \mathrm{~m}$ to $125 \mathrm{~m}$ towards the proximal part.

5. Hyvinkää (Ramsay 1931, site no 123; Donner 1952; Sauramo 1958, p. 82). North-east of the railway cutting through Salpausselkä I at Hyvinkää, there is a large area with an even surface mostly at about $125 \mathrm{~m}$, but with a stony ridge in the middle running in the direction of the moraine. On the basis of the structure of the material on the proximal side of this ridge, it was earlier concluded (Donner 1952) that at least this part of the endmoraine is not a marginal delta plain but an erosion surface formed later through redeposition of the material of a formerly higher ridge. On the basis of the observations on the bedding of the outwash material, dipping north-west towards the proximal side and particularly on the basis of horizontal silt layers found deeper down, it is likely that some parts of the even surface are erosional features. It is, however, not likely that the area $1 \mathrm{~km}$ broad and $3 \mathrm{~km}$ long at about $125 \mathrm{~m}$ consists entirely of an erosional surface formed in a comparatively short time. It is more likely that the feature represents a marginal delta plain built up to the water level, and that its surface has later been evened out by wave action, as many others of the lower deltas in Salpausselkä I. Immediately north-east of the delta at $125 \mathrm{~m}$ the surface of the moraine reaches $150 \mathrm{~m}$. The surface is in this part uneven with small knobs and kettle-holes and must therefore be considered to be a supra-aqueous, or possibly a sub-aqueous, feature and not a higher delta suface, as earlier concluded. There is thus probably only one delta plain present in Salpausselkä I at Hyvinkää.

6. Erkylä, Hausjärvi. North of Erkylä there is a short, but broad feeding esker which joins Salpausselkä I east of Erkylä. The topography of the moraine as well as the esker is here very irregular, with a number of kettle holes, but the hill Vastamäki north of Erkylänjärvi consists of an even marginal delta with ics plain at $150 \mathrm{~m}$. The area, at approximately the same altitude, of Salpausselkä I east of Erkylä, at Kirkkomäki, is similar to the 
higher area near Hyvinkää and most likely consists of a supra-aqueous feature, or possibly of a feature not built up to the surface of the water level.

7. Hikiä, Hausjärvi (Ramsay 1931, site no 122; Sauramo 1958 , p. 82). In the area south-east of Hikiä where an esker forks off from the proximal part of Salpausselkä I there is a large area with kettle holes, Pässinlukot and Nummenlukot. South-west of this area there is a small marginal delta with an even plain at $150 \mathrm{~m}$.

8. Hatlamminmäki, Hausjärvi (Ramsay 1931, site no 120; Sauramo 1958, p. 112). Below the top of the hill covered with till there is a well-developed highest beach level with a zone of exposed bedrock and boulders at $153 \mathrm{~m}$.

9. Hausjärvi (Ramsay 1931, site no 121; Sauramo 1958, p. 107). The above-mentioned esker starting at Hikiä has immediately west of Hausjärvi church a marginal delta with a plain at $150 \mathrm{~m}$, the highest part reaching $155 \mathrm{~m}$ and bordered in the north by an area of kettle holes. According to Sauramo (1958) that part of the marginal delta plain which is at about $150 \mathrm{~m}$ is an erosional surface.

10. Maavehmaa, Kärkölä (Leiviskä 1920, p. 40-42, 276; Ramsay 1931, site no 135; Okko 1962, p. 84, 112). In the Sakaramäki-Syrjämäki area Salpausselkä I consists of a narrow sandur-delta with the distal edge of the plain at $156 \mathrm{~m}$, at which altitude a clear beach has developed in places. Between the delta at Maavehmaa and that at Hikiä, site 7, Salpausselkä I has no well-developed deltas. At Kärkölä, for instance, there is a marginal formation reaching an altitude of $145 \mathrm{~m}$ but the outwash material only forms a sloping feature, which is probably subaqueous, in contrast to the supra-aqueous parts of Salpausselkä I at Hyvinkää, where the topography is irregular.

11. Läyliäinen, Loppi (area discribed by Ramsay 1931, site no 93; delta included on map by Aartolahti 1968, Appendix I). The esker south-west of Läyliäinen has a delta at about $145 \mathrm{~m}$ near Hyrynlammet.

12. Launonen, Loppi (Ramsay 1931, site no 95). Immediately north of Launonen the esker, which has a number of kettle holes, forms two separate delta plains at about $150 \mathrm{~m}$.

13. Valajärvi-Haapajärvi area, Renko and Janakkala (Ramsay 1931, site no 118; Sauramo 1958, p. 101-103; Virkkala 1961, Fig. 13, p. 229; Aartolahti 1968, Fig. 10, p. 47, 55, 71, Fig. 13, p. 72). South-west of Valajärvi, in Renko, the esker has a higher delta at $153-154 \mathrm{~m}$ as well as a lower sandur-delta, Valkealamminkangas, with a distal edge at about $126 \mathrm{~m}$. The esker in Janakkala north-east of Valajärvi has three deltas, an even delta plain at Kyöstilänharju at $155 \mathrm{~m}$, and two others at Lukkojenmaa to the north-west, also at $155 \mathrm{~m}$. Further to the north-west, south of Haapajärvi, there are three delta plains at an altitude of $127 \mathrm{~m}$.

14. Kiimankallio, Janakkala (Sauramo 1958, p. 110112). Surrounding the till-covered top of the hill rising well above the surrounding country is a zone with boulders and exposed bedrock marking the highest beach level in the area. The upper part of the zone is at $155 \mathrm{~m}$ and it is clearest on the south-western side of the hill.

15. Kelhä, Janakkala (Sauramo 1958, p. 108-109). At Linnamäki in the Rahittu esker there is a small delta plain at about $150 \mathrm{~m}$.

16. Tanttala, Janakkala (Sauramo 1958, p. 108). In the esker west of Tanttala there is at Tienhaara a delta plain at $145 \mathrm{~m}$, whereas the esker otherwise has a very irregular topography with kettle holes.

17. Rastila (Ikaloinen used by Ramsay and Sauramo, a name not used any more on new maps), Vanaja (Ramsay 1931, site no 112; Sauramo 1958, p. 108). There are two delta plains at $132 \mathrm{~m}$ on each side of the esker ridge fringed by deep kettle holes north-west of Kiianlinna.

On the map in Fig. 2 it can be seen how the deltas formed at one of the B levels, as well as the sites with the highest beach level at corresponding altitudes, occur in a broad belt bordered by deltas formed at the $\mathrm{g}$ level on the south-eastern side and deltas formed at the Y I level on the north-western side. The drop of level down to the Y I level is best seen at site 13. A line was drawn on the map to show, schematically, the approximate position of the ice margin at the time of the sudden drop of water level down to the Y I level. The line is similar to that drawn by Aartolahti (1968, Appendix I), whereas the line drawn earlier by Sauramo (1958, Fig. 19) suggested that there were lobes in the ice margin with bays in the places where eskers were formed. As the tracing of possible irregularities in the shape of the retreating ice margin requires a detailed study of the features formed at or near the ice margin, the line drawn in Fig. 2 must be taken as showing only the trend of the margin at the time when 
the water level dropped. A similar line is that which separates the deltas formed at the $\mathrm{g}$ level from those formed at the B level. The deltas of Salpausselkä I around Sääksjärvi, site 3, near Rajamäki, site 4, and at Hyvinkää, site 5, all belong to the g level, as well as the delta between lakes Vihtijäıvi and Alimmainen, site 2. The highest beach level at site 1 clearly represents the B level as well as the deltas at sites 6, 7 and 9 just inside Salpausselkä I north-east of Hyvinkää. Further to the north-east, at Maavehmaa, site 10 , the B level is already present on Salpausselkä I. The line drawn in Fig. 2 separating the $\mathrm{g}$ levels from the B levels thus does not follow Salpausselkä I but forks off from it in the southwestern part of the area investigated. Already the general distribution of the deltas at different altitudes shows that the deltas formed at the $\mathrm{g}$ level are older than those formed at the B level. This leads to the conclusion that there was a considerable transgression after, and perhaps already during, the formation of the deltas at the $\mathrm{g}$ level. This is even more clear when studying some areas more closely. The delta at B level at Erkylä, site 6, is part of a feeding esker inside Salpausselkä I. The area at the same altitude where the esker joins Salpausselkä has supraaqueous features which show that at the time when the ice margin still stood at Salpausselkä I the water level had not yet risen to the B level. The deltas formed at the $\mathrm{g}$ level, on the other hand, occur in areas lying between feeding eskers. The deltas at B level at Hikiä and Hausjärvi, sites 7 and 9, also belong to a feeding esker. As the eskers inside Salpausselkä and joining it were most likely formed later than the large deltas formed especially between the eskers, the only possible explanation is that the water level must have risen from the $\mathrm{g}$ level to the B level. The deltas formed at $g$ level were thus only preserved in areas, as at Hyvinkää and Rajamäki, from which the ice margin had withdrawn before the transgression, whereas in those areas where it was still at Salpausselkä I, material was accumulated at higher altitudes, sometimes, as at
Maavehmaa, as high as to the B level. As the relative rise in water level must be synchronous in the whole area the conclusion can be drawn that the various parts of Salpausselkä I were probably formed at slightly different times. The line in Fig. 2 separating the deltas formed at $\mathrm{g}$ level from the higher ones may, however, give an exaggerated picture of this difference. Lobes in the ice margin may have existed, for instance south-west of Hyvinkää, site 5, and the ice margin could have been close to Salpausselkä I still at the time when the water level had risen to the B level. At Vihtijärvi, site 2, the ice margin, however, was already some distance from Salpausselkä when the water level rose, as a delta was still formed at the g level at this site. The deltas formed at the $\mathrm{g}$ level differ slightly morphologically from those formed later at higher altitudes because they became submerged for some time, until the drop of water level after the formation of Salpausselkä II. Some erosion of the surface material altered the morphology of the deltas, sometimes to a large extent, as at Hyvinkää, but more often only slightly. Often the topset beds are missing, but where they occur in the deltas of the Salpausselkä endmoraines they are only $1-2 \mathrm{~m}$ thick. Erosion could, therefore, easily obliterate them. Meltwater channels, typical for many sandur-deltas formed at the B levels, as in the Lahti area, are missing in the deltas at g level, unless the channels in the distal parts in some deltas, as at Hyvinkää, are preserved remnants of them. Stony, oriented ridges have often been preserved, as in the deltas around Sääksjärvi, and the delta plains have often large boulders, of which some must be ice-rafted, as those of Viipuri rapakivi on the surface of the delta at Hyvinkää for which thete is no other possible explanation, as its rock outcrop occurs east of Hyvinkää in south-eastern Finland and not in an area over which the ice advanced to reach Hyvinkää.

The general age relationship between deltas formed at low altitudes, the $\mathrm{g}$ and Y I levels, and those at higher altitudes, the B levels, can 


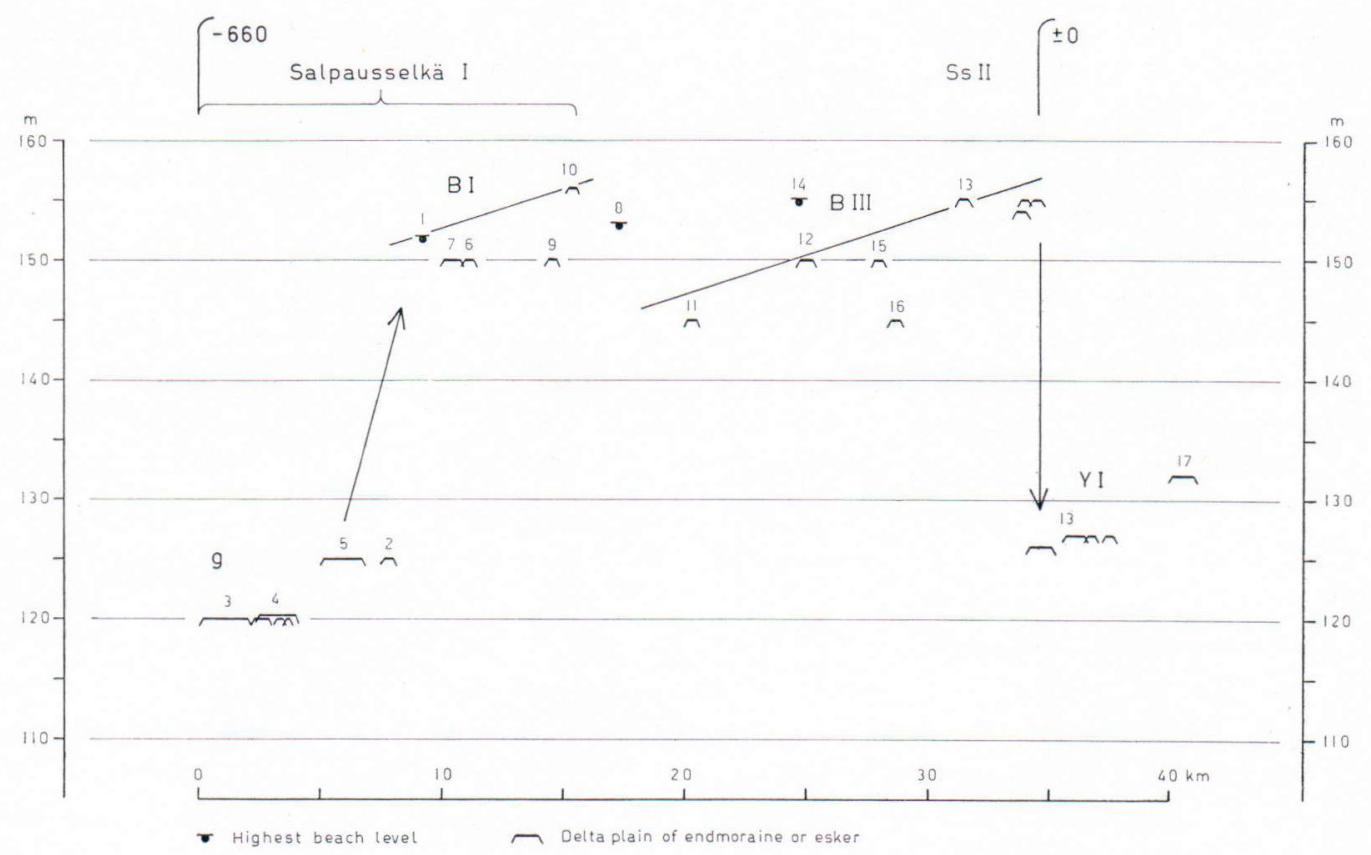

Fig. 3. Distance diagram of delta plains and highest beach level in area south of Hämeenlinna (for direction of base line see Fig. 2).

be seen on the map in Fig. 2, but for a closer study of the land/sea level changes in the atea investigated a shore-line diagram was constructed. The diagram in Fig. 3 is a distance diagram giving the altitudes of the marginal deltas as well as the highest beach levels along a line, just over $40 \mathrm{~km}$ long, at right angles to the general trend in the area investigated of the isobases of the recent uplift of land, as based on precise levellings (Kääriäinen 1966). As these isobases are rather irregular their general direction in an area as broad, in the direction of the isobases, as the one investigated, is difficult to determine. The type of diagram used, however, is better than a relation diagram for the study of the true shape of the shore-line surfaces (see discussion in Donner 1964). In the area studied a diagram of the latter type could not have been used because no older synchronous shore-line surfaces have been sufficiently well determined in the area which could be used as reference levels. In addition to errors caused by possible changes in the direction of the isobases on the position of the sites in the diagram in Fig. 3, the accuracy by which the altitudes have been determined varies. Many altitudes, as for the highest beach levels and for many distal parts of marginal deltas, have been levelled, but some altitudes for delta plains are based on the altitudes given on the topographical maps in 1 : 20000 with $5 \mathrm{~m}$ contours. The deltas used in the study are, however, often extensive and if more accurate determinations of the altitudes had been made, it would often have been difficult to determine which parts of the sloping delta plains correspond to the position of the water level at the time of their formation, especially as many delta plains lack a clearly developed distal edge.

In spite of the inaccurcies, mentioned above, in the determination of the altitudes used in the diagram in Fig. 3, the land/sea level changes during the withdrawal of the ice from the area 
investigated can be traced. After the formation of the deltas representing the $\mathrm{g}$ level at sites 2 , 3,4 and 5 , the relative rise of water level is shown by the deltas and beaches at an altitude at least $25 \mathrm{~m}$ higher. This level corresponds to the B I level mentioned in the introduction, and its present tilted position is indicated by a line across sites 1 and 10 , but sites 6 and 7 a few metres lower can also be counted as belonging to this level. The next clear shore-line which can be traced is that representing the level just before the final drainage of the Baltic Ice Lake inside Salpausselkä II, i.e. the B III level, represented by sites $11,12,13$ and 15 , whereas site 16 lies below this level. The position of the B II level, which should lie between B I and B III, can not be determined on the basis of the few observations presented in Fig. 3, but the highest beach levels at sites 8 and 14 probably represent this intermediate level, as may also the delta at site 9. The drop of the water level down to the Y I level is clear in Fig. 3 and some of the deltas at site 13 and the delta at site 17 were fomed at this first Yoldia level. From the altitudes of the deltas at Y I level, as well as at the $\mathrm{g}$ level, it can be seen that they both represent tilted shore-line surfaces, but they were not drawn in Fig. 3 on the basis of the few observations available. The position of the Y I level in the area investigated was earlier shown in a similar diagram as that in Fig. 3 by Sauramo (1933) for the deltas and shore-lines between Hyvinkää and Vanajavesi. Comparing the shore-lines determined in the diagram in Fig. 3 with the distribution of the sites, as shown in Fig. 2, it can be seen that the B I level is found at sites immediately northwest of the line separating the $g$ levels from the $B$ levels, and that the deltas representing the B III level are regularly found further north-west at or close to Salpausselkä II. The age relationship between the shore-lines suggested by the diagram is thus confirmed by the geographical distribution of the sites. In the varve chronology (Sauramo 1918, 1923) the halt at Salpausselkä I began at about -660 and the drainage of the
Baltic Ice Lake after Salpausselkä II corresponds to the zero year, \pm 0 . Within this time, as seen from Fig. 3, the transgression occurred during which the water level rose to the levels corresponding to the levels B I-B III of the Baltic Ice Lake. The rise of water level took place about $150-250$ years after the halt of the ice margin at Salpausselkä I, judging from the results of the varve counts in the area investigated (Sauramo 1918), which is between the years -400 and -500. This would leave $400-500$ years for the high position of water level of the Baltic Ice Lake in the Salpausselkä belt, and in this time the relative position of the sea level fell from the $\mathrm{g}$ level to $\mathrm{Y} \mathrm{I}$ by approximately 15 metres while the regression which took place from B I to B III in a slightly shorter time was $10-12 \mathrm{~m}$.

The results from the area investigated have not changed the previous concept about the drop of the level of the Baltic Ice Lake after the formation of Salpausselkä II, in the year \pm 0 , separating two different sediment facies in the varved clays (Sauramo 1923, p. 87). In the interpretation of the land/sea level changes put forward by Sauramo, as mentioned in the introduction and shown in Fig. 4, the drop of water level from the B I level to the $\mathrm{g}$ level during the formation of Salpausselkä I was correlated with the exceptionally thick varve - 435, containing sand, found only at Jokela south of Salpausselkä I (Sauramo 1918, Table IV; 1923, p. 122-129, Plate II; 1958, p. 76). The varves both below and above this thick varve are of the same thickness, but those above are described as symmict and those below as diatactic (Sauramo 1923, p. 86). The varves are, however, particularly distinct above the thick varve -435 and clearly different from the symmict varves formed after the formation of Salpausselkä II. If the conclusions by Sauramo about land/sea level changes based on the thick varve and the described change in varve structure are correct, they contradict the conclusions in the present study. On the other hand, it can be noted that the exeptionally thick varve of -435 was formed at a time at which the water 
level, according to the present results, had a considerable rise, between the years -400 and -500 . It may, therefore, be possible that the thick varve was formed as a result of the great change in water level, not a sudden drop as assumed by Sauramo, but a considerable rise. Further, as the thick varve has only been described from one locality, Jokela, it is not known in how large an area it was formed and it may occur in only a very restricted area.

\section{Lahti}

The broad endmoraine west of Lahti consists foremost of a chain of sandur-deltas with well preserved meltwater channels on the delta plains and with the distal edge at an altitude of $150 \mathrm{~m}$ near Lahti and rising towards the west to $160 \mathrm{~m}$ (Donner 1951, Sauramo 1958, Okko 1962). Whereas the marginal deltas further to the southwest, in the area investigated south of Hämeenlinna, represent both the g level and the B I level, the sandur-deltas in the Lahti area were all formed at the B I level. A clear beach is developed at the distal edge at this level, in some places closing the mouths of the channels found on the surface of the sandur-deltas, but the beach also occurs on the proximal side. This was by Sauramo (1940, 1958) considered to show that the water level had still stood at the B I level after the ice margin had retreated from the deltas and that the drop down to the g level here took place somewhere north of Salpausselkä I. No such assumption needs to be made if the water level stood at the $\mathrm{g}$ level before it rose to the B I level at which the deltas were formed. As no deltas are found at the $g$ level south of Salpausselkä I in the Lahti area it means that any outwash material deposited at that time is either underneath the sandur-deltas formed at the B I level or north of Salpausselkä I and that no recognisable features, as deltas, remain to show this lower position of water level. The ice-marginal features in the foreland show that there was a readvance of the ice margin before Salpausselkä I was formed (Okko 1962), at least close to Lahti. Further, Okko concluded, mainly on the basis of observations of the structure of Salpausselkä, that the distal parts of the endmoraine was here deposited before a transgression which reached the level of the highest beaches, i.e. B I, in the area. The shore bars closing the channels in the distal parts of the sandur-deltas do not necessarily mean that there was a rise in water level after the formation of the channels, because these may in places, where they are shallow, have been formed somewhat below the water level (Andersen 1960). When shore bars close channels several metres deep, however, a rise of water level was probably needed to form the bar, after the erosion of the channels at a lower level. The transgression at Lahti was estimated to be at least $10 \mathrm{~m}$, following an earlier high position, before the formation of Salpausselkä I, of the water level (Okko 1962). After the transgression the water level sunk to the B II level without an intermediate low position, as already demonstrated by Sauramo (1934, Fig. 5) when studying the area between Lahti and Lammi north-west of Lahti.

The evidence from the above-mentioned studies seems to indicate that the sandur-deltas in the Lahti area were formed after a local readvance of the ice margin and that the water level rose to the B I level during the formation of Salpausselkä I. After the withdrawal of the ice margin the water level fell to the B II level without there being any evidence of a big drop between the B I and B II levels. Compared with the area studied south of Hämeenlinna deltas formed at the $g$ level are missing in the Lahti area, but the structure of the sandur-deltas indicate that their distal and lower parts were formed before the water level had risen to the B I level.

\section{Utti}

Utti is one of the few parts of the Salpausselkä I endmoraine where a delta formed at the g level 
occurs together with a delta formed at the B I level (Fig. 1). At Utti airfield and south of Haukkajärvi there is an over $5 \mathrm{~km}$ long and in its broadest place over $1 \mathrm{~km}$ broad flat delta plain with the distal part at an altitude of $95 \mathrm{~m}$ (Sauramo 1958). Bordering this delta plain of the $g$ level in the east is a less extensive delta, in which the highest proximal parts are uneven and probably supra-aqueous, but where the distal part has an even plain at $120 \mathrm{~m}$. Between this delta plain, representing B I (Sauramo 1958), and that of the $\mathrm{g}$ level is a terrace-like feature at about 110 $115 \mathrm{~m}$, especially well-developed south-east of the $120 \mathrm{~m}$ delta. There is at Utti no conclusive evidence of the age relationship between the two deltas formed at the $\mathrm{g}$ level and the B I level. Using only the local evidence at Utti it seems as if the B I delta were younger than the delta at $\mathrm{g}$ level. The latter occurs mainly at one side, on the western side, of the broadest part of the Salpausselkä I endmoraine at Utti and has therefore probably been prevented from being covered by later accumulations at a higher altitude. Further, the terrace-like accumulation bordering the distal part of the higher delta at B I level is a feature typical for marginal deltas formed during a transgression (Andersen 1960). In comparing the altitudes of the two main deltas at Utti the difference of $25 \mathrm{~m}$ between the $\mathrm{g}$ delta and the B I delta is the same as the difference between these two levels in the area studied south of Hämeenlinna, as noted by Sauramo (1958).

\section{General conclusions}

In the study of the Salpausselkä belt south of Hämeenlinna the position of the ice margin inside Salpausselkä II at the time of the drainage of the Baltic Ice Lake, in the year \pm 0 of the varve chronology, down to the Yoldia I level, a drop of about $28 \mathrm{~m}$ was traced. In addition, it was demonstrated that the $g$ level of Salpausselkä I is older than the B I level, which means that there was a transgression of about $25 \mathrm{~m}$ at the time of, or in places shortly after, the formation of Salpausselkä I. The area south of Hämeenlinna is unique for the study of the age relationship between the $\mathrm{g}$ level and the B I level, because the deltas representing these two levels are welldeveloped and occur clearly separated. Further to the south-west along Salpausselkä I in the lower coastal areas the delta plains only represent the $\mathrm{g}$ level, whereas further east the delta plains only represent the B I level, as at Lahti, or when both the $\mathrm{g}$ level and the B I level are represented, as at Utti, their age relationship is not clear. From these two latter areas, however, there are no results which would contradict those from the area investigated south of Hämeenlinna; on the contrary, a relative rise of water level during the formation of Salpausselkä I is fully compatible with the interpretation of the formation of the marginal features both at Lahti and Utti. The levels of the Baltic Ice Lake in the Salpausselkä belt would thus consist of only B I, B II and B III, as represented in Fig. 4, of which B I would be represented by delta plains of Salpausselkä I or deltas just inside this moraine, B III by deltas of Salpausselkä II or deltas just inside it, up to the line at which the drainage occurred, and the B II by deltas or raised beaches occurring in an area between the two Salpausselkäs. In concluding that there was a transgression of $25 \mathrm{~m}$ from the $\mathrm{g}$ level to the B I level it was assumed, in agreement with Sauramo (1958), that the deltas at $\mathrm{g}$ level are marginal delta plains, which in places may be slightly eroded but which are primary features. It is not considered likely that such large deltas, formed in a relatively short time, are erosional features alone. At Utti, for instance, the even delta plain at $\mathrm{g}$ level is over $1 \mathrm{~km}$ broad in its broadest place and over $5 \mathrm{~km}$ long.

The new schemical land/sea level curve, presented in Fig. 4, differs in many respects from that constructed earlier by Sauramo, which had two drainages of the Baltic Ice Lake before the final drainage after the formation of Salpausselkä III. In the new curve there is only one trans- 


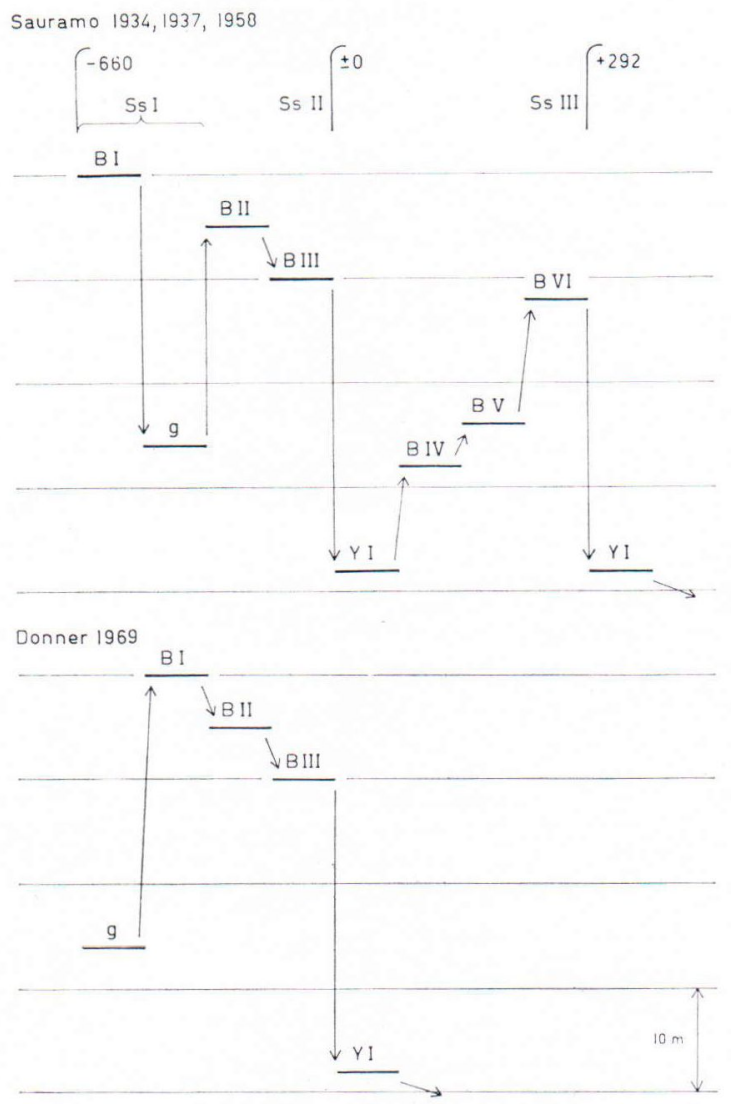

Fig. 4. Land/sea level changes during the formation of the Salpausselkä endmoraines according to Sauramo and as concluded in the present investigation. Years refer to varve chronology for southern Finland established by Sauramo.

gression, from the g level up to the first level of the Baltic Ice Lake, B I, and after a regression of about $10 \mathrm{~m}$, represented by the two lower levels of the Baltic Ice Lake, B II and B III, the final drainage down to the Y I level. A new damming up of the waters did not occur after this, according to the present results, as mentioned in the introduction. Some dates of the varve chronology are given in Fig. 4, but before discussing their significance in correlating the events with the development of the Baltic, a closer analysis of the relationship of the three $B$ levels and the $g$ level to the formation of the two Salpausselkäs is given.
In Fig. 5 three schematical models are given of the relationship between Salpausselkä $\mathrm{I}$ and the $\mathrm{g}$ level, the B I and B II levels. In Fig. 5 a Salpausselkä I was formed as a delta (or as several deltas) at $\mathrm{g}$ level and after the retreat from the moraine the water level rose and a delta was formed in an esker at the B I level. After further retreat of the ice margin deltas were formed at the B II level. An example of an area of this kind is that around Sääksjärvi and Vihtijärvi, sites 2 and 3. In Fig. $5 \mathrm{~b}$ the water level rose when the ice margin was still at Salpausselkä I and, therefore, in ideal circumstances, a delta was first formed at $\mathrm{g}$ level and later at B I level. After the ice margin had retreated the esker deltas were formed at B II level. Such an area is Utti. In Fig. $5 \mathrm{c}$ the outwash material was first deposited when the water level stood at the g level, but later when it rose to the B I level the final delta covered the deposits formed in more shallow water and built up a delta to the B I level. B II is also here represented in eskers

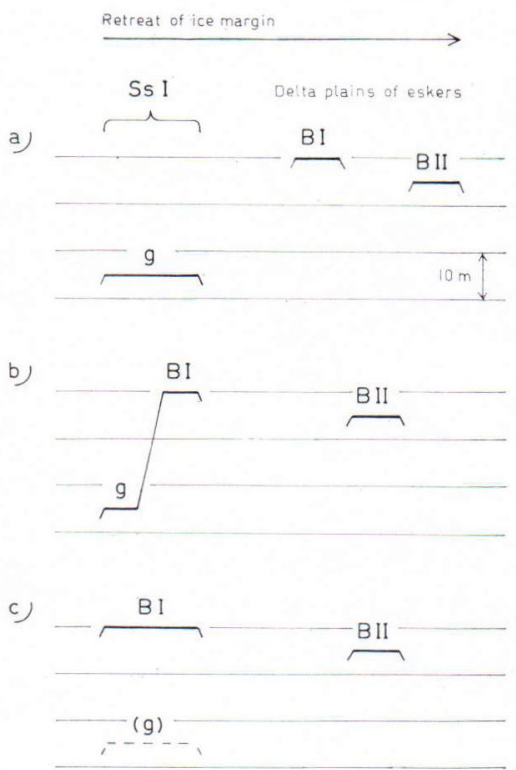

Fig. 5. Three examples of the levels at which the delta plains of Salpausselkä I and the delta plains inside this endmoraine were formed. 
inside Salpausselkä I. The Lahti area represents an area of this third type. A forth possibility is that the $\mathrm{g}$ level is represented south of Salpausselkä, but such a case has not been found. At Lahti, however, there is some indication of a readvance, which probably resulted in an overriding of the ice over sediments formed during the low position of the water level, before it rose to the B I level. The schematically drawn examples in Fig. 5 show that, as the land/sea level fluctuations must be synchronous, the morphological feature known as Salpausselkä $I$ is not an endmoraine built up exactly in the same time span everywhere, or more precisely, the ice margin started to retreat from Salpausselkä I earlier in some areas (Fig. $5 \mathrm{a}$ ) than in others (Fig. $5 \mathrm{~b}$ and $5 \mathrm{c}$ ). The difference in age is, however, only of the order of about 100 years.

The varve chronology established for southern Finland by Sauramo can directly be correlated with the withdrawal of the ice margin in the area studied south of Hämeenlinna. The last drainage of the Baltic Ice Lake occurred in the Salpausselkä belt just after the formation of Salpausselkä II and corresponds to the year \pm 0 in Sauramo's varve chronology (Sauramo 1918, p. 14), where a clear change in varve structure is observed. As no other similar drainage can, on the basis of the present interpretation, be demonstrated to have occurred either before or later than the year \pm 0 , it can be correlated with the last drainage of the Baltic Ice Lake at Billingen, in the year 8213 B.C. according to the latest revised dating of the Swedish varve chronology (Nilsson 1968). The new connection with the ocean through Middle Sweden marked the beginning of the Yoldia Sea, but salt water did not penetrate into the Stockholm area until 8015 B.C., i.e. 198 years after the drainage at Billingen (Nilsson 1968). In the area studied in southern Finland the change-over from diatactic to symmict clay occurred in the year +292 , in 7921 B.C., which is 94 years later than in the Stockholm area. Even if the varve chronology can not be considered conclusive as long as it is not firmly connected with present time, it does give a means for correlations between Sweden and Finland.

The date given above for the drainage at Billingen leads to the conclusion that the halt of the ice margin at Salpausselkä I began 8873 B.C. and that the time during which the marginal deltas at $\mathrm{g}$ level were formed, before the rise of the water level to the B I level, ended about 8600 B.C. -8700 B.C., accounting for about 150 -250 years for the formation of the features at $\mathrm{g}$ level, as earlier concluded. Thus, the following correlation of the varve chronology with the retreat stages would be obtained, using as basis the correlation of the year \pm 0 of Sauramo's varve chronology with the year 8213 B.C.

$$
\begin{aligned}
& \text { Varve chronology } \\
& +292=7921 \text { B.C. Influx } \\
& \text { of salt water in southern } \\
& \text { Finland } \\
& \text { Y I } \pm 0=8213 \text { B.C. Drain- } \\
& \text { age of Baltic Ice Lake at } \\
& \text { Billingen }
\end{aligned}
$$

Salpausselkä II B III

\section{B II}

$$
\text { Salpausselkä I }\left\{\begin{array}{l}
\text { B I } \quad 8600-8700 \text { B.C. } \\
g \quad-660=8873 \text { B.C. }
\end{array}\right.
$$

If the correlation above is correct, the g level in southern Finland was formed during a time between 8873 B.C. and 8600 B.C. -8700 B.C. when there was a connection between the Baltic and the ocean and, therefore, the water level in both was the same. The use of the term $g$ level, taken from the division of the shore-lines in northern Fennoscandia (Tanner 1930), as mentioned before, is not entirely suitable any more, because recent studies of the shore-lines in northern Norway have shown that Tanner's g level only in some areas corresponds to the shore-line $\mathrm{S}_{0}\left(=\mathrm{P}_{12}\right)$ (Holtedahl 1960, Andersen 1965), which was formed at the same time as the deltas at $g$ level in southern Finland. To avoid further confusion in the terminology for the levels in the 
Salpausselkä belt the term g level was, however, retained in the present study, but only as a purely local term without implying any connection with shore-lines elsewhere.

In assuming that the $\mathrm{g}$ level was formed at a time when the Baltic Ice Lake for at least a couple of hundred years about 8600 B.C. -8800 B.C. stood at the same level as the ocean, it follows that a temporary connection with the ocean must have been open at this time, about 400-600 years before the final drainage of the Baltic Ice Lake at Billingen in 8213 B.C. Where this possible connection was situated can not be determined in the area investigated in southern Finland. On the basis of recent investigations in eastern Finland (Hyvärinen 1966) it seems probable that the ice margin still at the time of the formation of Salpausselkä I prevented the waters of the Baltic Ice Lake discharging through northeastern Finland to the White Sea. Local icedammed lakes possibly existed in north-eastern Finland but were hardly connected with the Baltic through eastern Finland. The fluctuations in the water level of the Baltic Ice Lake were, therefore, probably entirely determined by the withdrawal of the ice margin in Sweden. A similar damming up of the waters of the Baltic Ice Lake as that in Finland during the formation of the Salpausselkäs has been observed in the south Baltic. In Lithuania, for instance, the water level was high between about 9000 B.C. and the drainage of the Baltic Ice Lake after a transgression of at least $20 \mathrm{~m}$ from a low position of the water level about 10000 B.C. -9000 B.C. (Gudelis

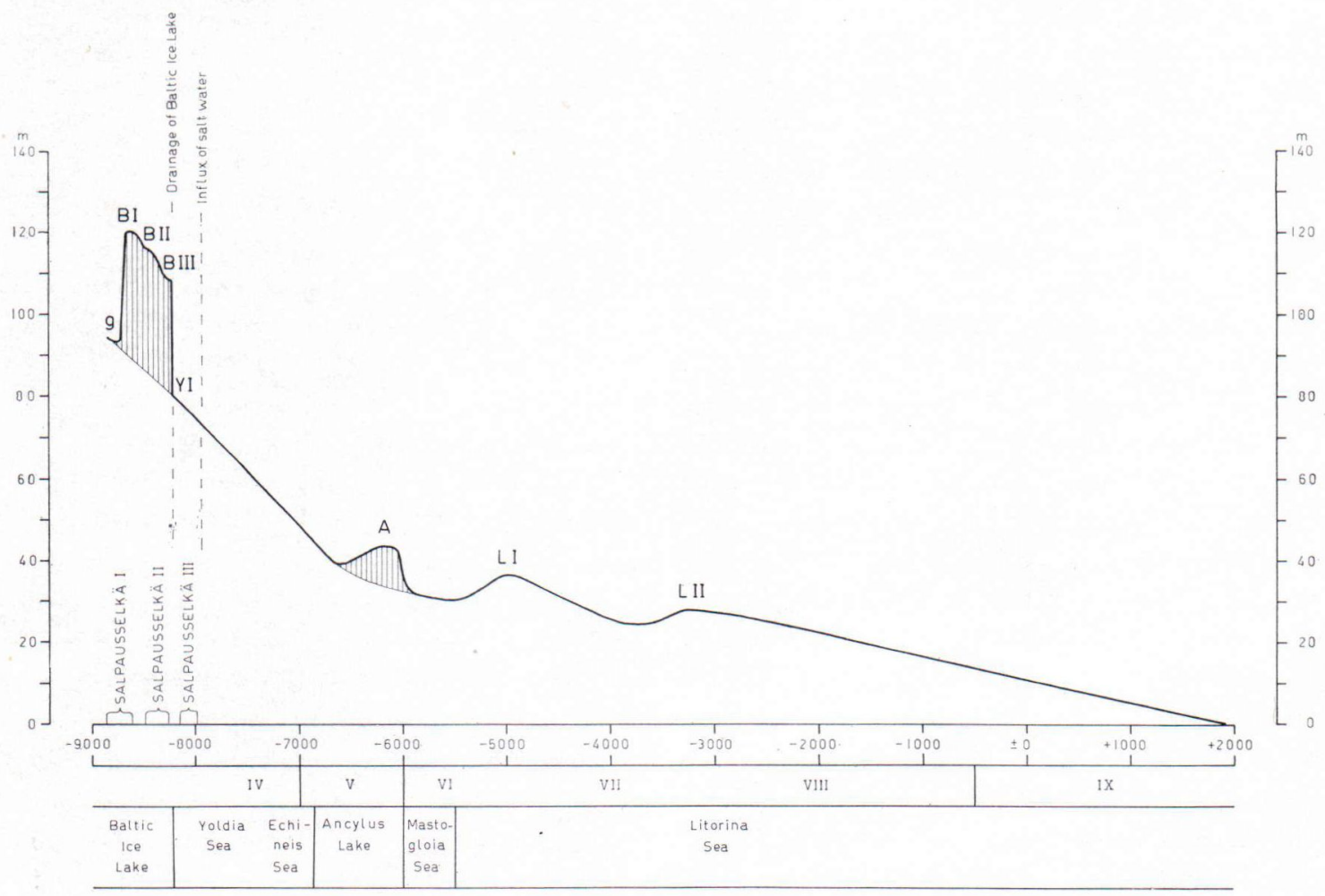

Fig. 6. A curve for the land/sea level changes at Helsinki compared with pollen stratigraphy and the stages in the development of the Baltic. The main shorelines g, B I- B III, Y I, A, L I and LII are shown as well as the influence on the land/sea level changes the damming up of the waters had in the Baltic during the times it was an independent lake isolated from the ocean. 
1961). Similarly, a high position of the water level, after a transgression, of the Baltic Ice Lake before it was drained was described by Berzin (1967) in an account of a deep boring through a buried valley in the Gulf of Riga. Thus, it can be seen that the land/sea level changes found to have taken place in southern. Finland during the last thousand years in the history of the Baltic Ice Lake can also be traced elsewhere and that these changes show the same pattern. It is important to note that the results from Lithuania are based on stratigraphical changes while the results from Finland are based on morphological features.

The results obtained about the land/sea level changes in the area studied south of Hämeenlinna, as presented in Fig. 3 and Fig. 4, were added to those earliet obtained from southwestern Finland (Donner 1964), and a curve was constructed to show the changes during the last 11000 years (Fig. 6). Using the distance diagram of the shore-lines of south-western Finland (Donner 1964, Fig. 11) the observations from the area south of Hämeenlinna were transferred to the somewhat lower isobases, to the Helsinki atea, for which a curve was earlier constructed (Donner 1964, Fig. 12). The new results extend the curve back in time by nearly 700 years. Apart from adding the new results to the old ones (see also Donner 1968), two parts of the old curve were revised. The curve just after 8000 B.C. is not as steep as was earlier assumed and, further, new radiocarbon determinations in south-western Finland, as summarized by Alhonen (1968), place the zone boundaty V/VI at about 6000 B.C. and not at 6300 B.C. This change in dating means that the transgression of the Ancylus Lake lasted for a longer period of time than earlier assumed. The zone III petiod, as earlier separated in the pollen stratigraphy, was omitted as its significance close to the retreating ice margin was later found to be of less general value (Donnet 1967).

In Fig. 6 those land/sea level changes which were a result of transgressions within the Baltic when it was an independent lake isolated from the ocean, i.e. at the time of the Baltic Ice Lake and the Ancylus Lake, were marked separately. When these transgressions are discounted the curve for the land/sea level changes, dependent on the isostatic and eustatic changes alone, falls regula1ly until about 5500 B.C., after which it is interrupted by the Litorina transgessions $\mathrm{L} \mathrm{I}$ and L II. The curve is similar in shape to all those curves from areas in which the eustatic rise of sea level overtook the isostatic recovery of the eatth's crust after a period of rapid recovery immediately after deglaciation, as seen in a comparison, for instance, with some of the curves for areas bordering the North Sea (see summary by Andersen 1960).

\section{REFERENCES}

Aartolahtr, T. (1968) Die Geomorphologie des Gebiets von Tammela, Südfinnland. Fennia 97 (7), 97 pp.

Alhonen, P. (1968) Radiocarbon ages from the bottom deposits of Lake Sarkkilanjärvi, south-western Finland. Bull. Geol. Soc. Finland 40, 65-70.

Andersen, B. G. (1960) Sørlandet i sen- og postglacial tid (Summary: The late- and postglacial history of Southern Norway between Fevik and Åna-Sira). Norges Geol. Unders. 210, 142 pp.

- (1965) The Quaternary of Norway (in: Rankama, The Quaternary, Volume 1). John Wiley \& Sons Ltd., London, 91-138.
BERzIN, L. E. (1967) On the age and sea level oscillations of early and middle Holocene Baltic Sea transgressions in the upper part of the Gulf of Riga (in Russian with Summaries in English and German). Baltica 3, 87-104.

Donner, J. J. (1951) Pollen-analytical studies of lateglacial deposits in Finland. C. R. Soc. géol. Finlande 24; Bull. Comm. géol. Finlande 154, 1-92.

- (1952) Om Salpausselkä vid Hyvinge (Summary: On Salpausselkä at Hyvinkää). Terra 64, 1-5.

- (1964) The Late-glacial and Post-glacial emergence of south-western Finland. Soc. Scient. Fennica, Comm. Physico-Math. 30 (5), 47 pp. 
- (1965) The Quaternary of Finland (in: Rankama, The Quaternary, Volume 1). John Wiley \& Sons Ltd., London, 199-272.

- (1967) The Late-glacial and early Post-glacial pollen stratigraphy of southern and eastern Finland. Soc. Scient. Fennica, Comm. Biol. 29 (9), 24 pp.

- (1968) The Late-glacial and Post-glacial shore-line displacement in south-western Finland (in: Means of correlation of Quaternary successions). Univ. of Utah Press, Salt Lake City, 367-373.

Gudelis, V. K. (1961) Outline Geology and Palaeogeography of the Quaternary (Anthropogen) in Lithuania (in Russian with Summary in English). Instytut Geologiczny, Tom 34, Warszawa 1961, Wydawnictwa Geologiczne, 423-479.

Holtedahl, O. (1960) Geology of Norway. Norges Geol. Unders. 208, 540 pp.

HYvärINEN, H. (1966) A shore-line diagram for the easternmost section of the Salpausselkäs. Soc. Scient. Fennica, Comm. Physico-Math. 33 (4), 7 pp.

KÄÄRIÄINEN, E. (1966) The second levelling of Finland in 1935-1955. Suomen Geod. Lait. Julk. - Veröff. Finn. Geod. Inst. 61, 313 pp.

Leiviskä, I. (1920) Der Salpausselkä. Fennia 41 (3), 388 pp.

Nilsson, E. (1968) Södra Sveriges senkvartära historia (Summary: The Late-Quaternary history of southern Sweden). Kungl. Svenska Vetenskapsakad. Handl., Fjärde Ser. 12: 1, 117 pp.

Окко, M. (1962) On the development of the first Salpausselkä, west of Lahti. Bull. Comm. géol. Finlande 202, 162 pp.

- (1965) M. Sauramo's Baltic Ice Lake B IV-B VB VI; a re-evaluation. Ann. Acad. Scient. Fennicae Ser. A, III, 84, 36 pp.

RAMSAY, W. (1917) De s.k. marina gränserna i södra Finland. Förberedande meddelande (Referat: Die s.g. marinen Grenzen im südlichen Finnland). Fennia 40 (7), 8 pp.
- (1922) Randdeltan och strandlinjer i Salpausselkäbältet. Terra 34, 161-166.

- (1931) Material zur Kenntnis der spätglazialen Niveauverschiebungen in Finnland. Fennia 54 (3), 145 pp.

Sauramo, M. (1918) Geochronologische Studien über die spätglaziale Zeit in Südfinnland. Fennia 41 (1), 44 pp.

- (1923) Studies on the Quaternary varve sediments in southern Finland. Fennia 44 (1); Bull. Comm. géol. Finlande 60, 164 pp.

- (1928) Úber das Verhältnis der Ose zum höchsten Strand. Fennia 51 (6); Bull. Comm. géol. Finlande 84, 18 pp.

- (1933) Yoldiameri entisten ja nykyisten tutkimusten valossa (Summary: The Yoldia Sea in the light of earlier and modern research). Terra 45, 1-14.

- (1934) Zur spätquartären geschichte der Ostsee. C. R. Soc. géol. Finlande; Bull. Comm. géol. Finlande 104, $28-87$.

- (1937) Das System der spätglazialen Strandlinien im südlichen Finnland. Soc. Scient. Fennica, Comm. Physico-Math. 9 (10), 23 pp.

- (1940) Suomen luonnon kehitys jääkaudesta nykyaikaan. Porvoo-Helsinki, 286 pp.

- (1958) Die Geschichte der Ostsec. Ann. Acad. Scient. Fennicae Ser. A, III, 51, 522 pp.

TANner, V. (1930) Studier över kvartärsystemet i Fennoskandias nordliga delar IV (Résumé: Études sur le système quaternaire dans les parties septentrionales de la Fennoscandie IV). Fennia 53 (1), 589 pp.

VirkKaLA, K. (1961) On the glacial geology of the Hämeenlinna region, southern Finland. C. R. Soc. géol. Finlande 33; Bull. Comm. géol. Finlande 196, 215 242.

- (1963) On ice-marginal features in southwestern Finland. Bull. Comm. géol. Finlande 210, 76 pp.

Manuscript received, January 10, 1969. 